Original research article

\title{
Factors associated with falls in hospitals: outcomes for nursing care
}

\author{
Hana Hajduchová ${ }^{*}$, Iva Brabcová ${ }^{1}$, Valérie Tóthová ${ }^{1}$, Sylva Bártlová ${ }^{1}$, Martin Doseděl ${ }^{2}$, \\ Josef Malý ${ }^{2}$, Jiří Vlček ${ }^{2}$ \\ ${ }^{1}$ University of South Bohemia in České Budějovice, Faculty of Health and Social Sciences, Institute of Nursing, Midwifery and Emergency Care, \\ České Budějovice, Czech Republic \\ ${ }^{2}$ Charles University, Faculty of Pharmacy in Hradec Králové, Department of Social and Clinical Pharmacy, Hradec Králové, Czech Republic
}

\begin{abstract}
Aim: The aim of this research was to carry out an analysis of falls of hospitalized patients in 2017. They occurred at 16 selected wards in 4 hospitals in South Bohemia. The falls of hospitalized patients are the most frequent negative events in hospitals.

Materials and methods: The data regarding falls in hospitals were coded and databased by authorized employees in "Monitoring of the risk factors of falls and their analysis". They were later statistically analysed using the SASD programme. A total of 280 falls were analysed. Results: Most falls occurred at subsequent care wards - 48.9\%. 44.3\% of falls occurred at internal wards and $6.8 \%$ at surgical wards. Almost half $(46.5 \%)$ concerned patients who had been hospitalized for 1 to 7 days. The average age of the patients who had fallen was 76.9 years. Most falls occurred in patients' rooms $-78.0 \%$ and, in $93.3 \%$ of the cases, a medical worker was not present when the fall occurred. In the last 12 months, more than one third of patients have experienced a fall (39.8\%). The riskiest period of the day was between 22:00 and $5: 59$ (35.8\% of falls). Most frequently (31.6\%), a patient fell off their bed. $41.8 \%$ of patients were not injured. The most frequent internal cause was imbalance or dizziness (57.1\%) and $34.4 \%$ suffered from confusion.

Conclusions: Considering the above-mentioned results, we recommend a change in the control system and interventions using IT technologies and systems.
\end{abstract}

Keywords: Fall analysis; Czech Republic; Hospitalized patients; Nursing care; Risk factors

\section{Introduction}

Patients' safety is a priority for medical workers (Godlock et al, 2016; Pokojová and Bártlová, 2018). The falls of hospitalized patients are one of the most frequent negative events in hospitals (Williams et al., 2014) and a common cause of avertable injuries. Events causing a serious injury of a hospitalized patient are considered unacceptable by some authors (Barker et al., 2016).

Approximately one third of the annual 700,000 to 1 million falls in USA hospitals could be prevented (Cameron et al., 2010), especially regarding elderly patients.

A fall is defined as a change of position that ends with the contact of the body with the ground; it can result in consciousness and injury (Topinková, 2005). A patient does not plan to drop (slip down) to the floor or a pad. It is a non-intentional act when a person is suddenly on the ground or a lower surface with a present witness, or they report the accident by themselves (there are no witnesses). We cannot consider an intentional movement a fall (Pokorná et al., 2017). A fall can cause light injuries as well as severe injuries and even death (Cox et al., 2015; Ganz et al., 2013). In a number of cas- es, falls repeat (Healey, 2016). A fall can also affect expected therapeutic procedures and prolong hospitalization (Dunne et al., 2014; Wong et al., 2011) or have a negative effect on patients' future quality of life (Bradley et al., 2010). Regarding frail geriatric patients, falls can cause a decreased mobility and weaken their confidence and independence. There are a number of methods regarding the prevention of falls, which are used as part of individual or multi-factorial programmes (Ang et al., 2011; Cumming et al., 2008; Dykes et al., 2010), e.g. a standardized identification of risk patients immediately after admission to a hospital (Hefner et al., 2015), rescreening of such risk, education of patients (Lee et al., 2014) and their family members, as well as intervention using modern IT technologies and systems (Bayen et al., 2017; Cuttler et al., 2017; Votruba et al., 2016). It is also important to monitor the effectiveness of preventative programmes and register the results of other interventions (Horová et al., 2017). The causes of falls regarding hospitalized patients are multi-factorial (Bittencourt et al., 2017; Rheaume and Fruh, 2015). Considering many factors which are involved in patients' falls (Kang and Song, 2015; Oliver et al., 2000), the causes, i.e. risk factors, can be divided into two main groups - internal and external (Zhao and Kim, 2015). Internal factors include changes associ-

\footnotetext{
* Author for correspondence: Hana Hajduchová, University of South Bohemia in České Budějovice, Faculty of Health and Social Sciences, Institute of Nursing, Midwifery and Emergency Care, U Výstaviště 26, 37005 České Budějovice, Czech Republic; e-mail: hajducho@zsf.jcu.cz; http://doi.org/10.32725/kont.2019.004 
ated with physical or psychological impairments and changes due to the patient's age. $20-30 \%$ of falls are caused by external factors (Healey and Scobie, 2007) or factors which are not in the organism but include unknown environment, mechanical obstacles, footwear and clothes and pharmacotherapy (Chang et al., 2011; Lamis et al., 2012). The risk of falls is increased by the increased number of risk factors. It is important to assess every patient's risk factors (Katsulis et al., 2010; McKechnie et al., 2017) and use this information for prevention (Lang et al., 2014; Twibell et al., 2015). It is important to strengthen patients' active role in healthcare (Twibell et al., 2015; Tzeng and Yin, 2014). Nurses' knowledge and experience may be of great importance in decreasing the risks of falls (Barrett et al., 2017; King et al., 2018; Luzia et al., 2018). Teamwork, sharing and providing information on the risk factors of individual patients and good communication among medical workers is a necessary requirement. Shumba and Abraham (2017) emphasize regular training of employees and supervision. The goal of this research was to carry out the analysis of falls of hospitalized patients in 2017 at 16 selected wards in 4 hospitals in South Bohemia.

\section{Materials and methods}

We carried out the analysis of falls of hospitalized patients in 2017 at 16 selected wards and uploaded it to the interactive database of "Monitoring of fall risk factors and their analysis" (Pharma Portal EU). We monitored all falls at departments with the highest number of falls in every co-operating hospital. The purpose of this interactive database in the mentioned project is the monitoring of falls at 6 internal departments, 2 surgical departments, 5 departments of subsequent care, 1 rehabilitation department, 1 department of pulmonary diseases and 1 psychiatric department in 4 hospitals in South Bohemia, i.e. Hospital České Budějovice, a. s., Hospital Jindřichův Hradec, a. s., Hospital Tábor, a. s., and Hospital Písek, a. s. Authorized employees (nurses, doctors, administrative workers) uploaded the data on individual patients in the database. The patients experienced falls while they were hospitalized, i.e. between January and December of 2017. The workers were selected by their superiors in every hospital. 280 falls were analyzed. Hospital Tábor, a. s., had 24.8\% of falls, Hospital České Budějovice, a. s., 35.1\%, Hospital Jindřichův Hradec, a. s., had 14.2\% and Hospital Písek, a. s., had $25.9 \%$ of falls. The interactive database is focused on the risk factors of falls and is one of the bases of the project carried out at the Faculty of Health and Social Sciences in České Budějovice, which co-operates with the Faculty of Pharmacy in Hradec Králové. The research protocol was revised due to the strict rules of GDPR and approved by the Ethical Committee of the Faculty of Pharmacy in Hradec Králové, the Ethical Committee of the Faculty of Health and Social Sciences and the managements of the involved hospitals.

The data the employees uploaded to the database were divided into the following sections: (1) risk factors of falls; (2) description of falls; (3) patient's personal anamnesis; (4) physical and laboratory examination; (5) medicines used by patient; (6) doctor's assessment of health condition; (7) pharmaceutical intervention; (8) pharmaceutical assessment; (9) doctor's feedback to pharmacist. We used the assessment scales for the screening of the risks of falls from the hospitals.

The data on the falls from each hospital were coded and uploaded to the database. We used the SASD programme to carry out their statistical analysis.
While analyzing the relationships, we applied (by the characters and the number of observations) the chi-squared test of goodness and the test of independence. We also calculated the Pearson's contingency coefficient, the standardized Pearson's contingency coefficient, the Cuprov coefficient, the Cramer coefficient, the Kruskal-Wallis coefficient, Spearman coefficient and correlation coefficient.

\section{Results}

\section{The basic characteristics of the patients who experienced falls}

The hospital departments were divided into three groups: internal departments (which included psychiatric and rehabilitation departments), surgical departments and the departments of subsequent care (Table 1 ). The patients were divided into 5 groups by age (20-60, 61-70, 71-80, 81-90 years and 91 and older) (Table 1). Their average age was 76.9 years. We identified a statistically significant relationship between gender and age. The sample group included more women between 81 and 90 years, and men were between 20 and 60 years old $(p<0.01)$. Almost one half of falls $(46.5 \%)$ concerned patients who had been hospitalized for 1 to 7 days, and 35.8\% were patients who had been hospitalized for 8 to 30 days.

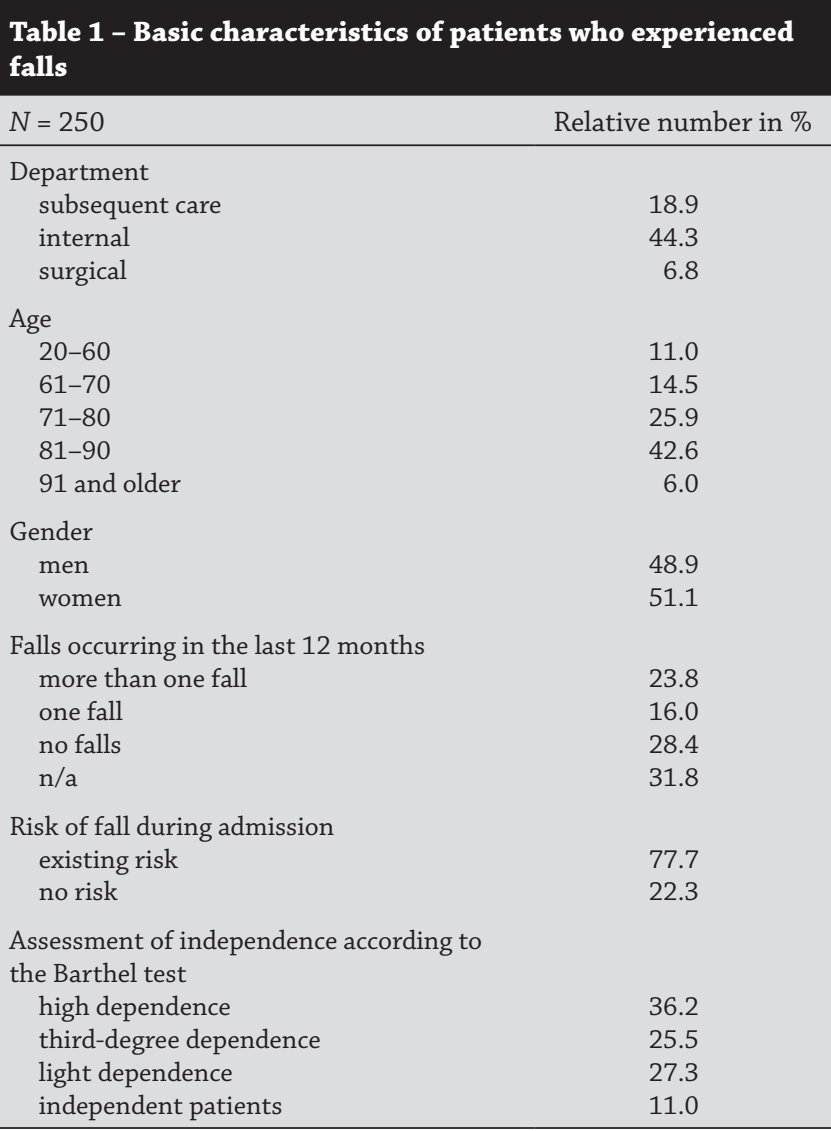

The assessment of independence, according to the Barthel test carried out during admission to the department where a fall occurred, is shown in Table 1. Other indicators of the level of patients' independence and the level of nursing care are presented by the legally established categories of patients. We learned that $7.1 \%$ of patients from our sample group had been 
included in the 1st category on the day a fall occurred. They were self-sufficient and independent of the basic nursing care. $22.3 \%$ were included in the 2 nd category. These patients are usually partially self-sufficient, able to take care of themselves with assistance and capable of movement with assistance or by themselves using a wheelchair. $54.6 \%$ were included in the $3 r d$ category. $16.0 \%$ were included in the 4 th category. They were immobile, non-self-sufficient or lucid, totally immobile or incontinent and required nursing assistance with the most common tasks.

\section{The mobility of patients before falls}

Out of the total 280 cases of falls, $23.4 \%$ occurred in patients who could walk without assistance, $26.6 \%$ used an aid or a wheelchair to move, $21.3 \%$ needed assistance, $24.5 \%$ were partially mobile (they could sit and move on their bed but could not walk) and $4.2 \%$ were totally immobile. $46.5 \%$ wore glasses or had eyeglasses, $3.5 \%$ had a hearing aid, $14.5 \%$ needed crutches ( $2.5 \%$ obtained them when they were hospitalized), $2.7 \%$ needed a walking stick, $18.1 \%$ needed a walking aid (13.8\% obtained it in hospital), 2.5\% used a wheelchair and $1.8 \%$ had a pacemaker. Patients at internal departments had crutches more frequently than patients at other departments $(p<0.05)$. Patients at the departments of subsequent care used a walking aid more frequently than patients at other departments $(p<0.001)$ and obtained it during hospitalization more frequently than patients at other departments $(p<0.05)$.

\section{The psychological condition of patients before falls}

$50.7 \%$ of the patients in our sample group showed no psychological or psychiatric symptoms, $34.4 \%$ were confused, $14.5 \%$ were restless, $2.1 \%$ suffered from depression, $20.0 \%$ suffered from dementia and $6.4 \%$ suffered from anxiety. The study proved a statistically significant relationship between gender and dementia before the fall. We recorded a higher number of women suffering from dementia before the fall $(p<0.05)$. The research also proved a statistically significant relationship between age and the absence of psychological and psychiatric symptoms before the fall. Psychological and psychiatric symptoms before the fall most frequently occur at the age between 61 and 80 years $(p<0.05)$. The research showed a statistically significant relationship between age and restlessness before the fall. At the age between 20 and 60 years, restlessness before the fall occurred more frequently than at other age groups $(p<0.01)$

\section{Other risk factors}

Other risk factors include problems with food or liquid intake (12.1\% of patients in our sample group), IV therapy (24.5\%), pain (19.9\%), neurological diseases (13.8\%), severe joint diseases causing restricted mobility $(4.6 \%)$, post-surgery condition $(6.7 \%)$, incontinence $(28.7 \%)$, fear of falling $(13.1 \%)$, rehabilitation (25.9\%) or the use of a compensation aid (12.8\%). Sensory impairments are another risk factor. 6.7\% had logopaedic problems, $31.9 \%$ had problems with vision and $9.9 \%$ of patients had hearing problems.

\section{Details of falls: time, place and the activity during a fall}

The time of fall, place and the activity during a fall are shown in Table 2. We tried to learn whether there was a relationship between the department type and the time of a fall. Regarding this sample group of patients, we did not identify a statistically significant relationship between the type of department and the time of falls. The time of falls at the individual depart- ments was not statistically significantly different. We did not identify a statistically significant relationship between the time of falls and the activities during falls. We did not identify a statistically significant relationship between the time of falls and the place of falls.

\begin{tabular}{|c|c|}
\hline$N=280$ & Relative number in $\%$ \\
\hline $\begin{array}{l}\text { Time } \\
\text { between } 6: 00 \text { and } 11: 59 \\
\text { between } 12: 00 \text { and } 16: 59 \\
\text { between } 17: 00 \text { and 21:59 } \\
\text { between 22:00 and 5:59 }\end{array}$ & $\begin{array}{l}22.7 \\
23.0 \\
18.5 \\
35.8\end{array}$ \\
\hline $\begin{array}{l}\text { Place } \\
\text { in the room } \\
\text { in the corridor } \\
\text { at the toilet/in the bathroom } \\
\text { outside the building/outside } \\
\text { elsewhere (swimming pool, corridor in } \\
\text { front of the room, smoking room, nearby } \\
\text { room, outpatients waiting room) }\end{array}$ & $\begin{array}{r}78.0 \\
7.8 \\
11.0 \\
1.4 \\
1.8\end{array}$ \\
\hline $\begin{array}{l}\text { Activity during a fall } \\
\text { from a bed } \\
\text { during transport (bed, chair, trolley/cart) } \\
\text { walking with an aid } \\
\text { assisted walking } \\
\text { other activities (bending, reaching for } \\
\text { something) } \\
\text { other (most frequently, non-assisted } \\
\text { walking or without an aid, voluntary bed } \\
\text { leave) }\end{array}$ & $\begin{array}{r}31.6 \\
24.1 \\
9.2 \\
0.7 \\
7.1 \\
\\
27.3\end{array}$ \\
\hline
\end{tabular}

We identified a statistically significant relationship between the place and activity during falls $(p<0.001)$. In the rooms, falls from beds and during transports are significantly more frequent. In the corridors, the falls are significantly more frequent when patients walk without assistance or with a compensation aid (walking aid, walking stick, crutches).

The causes of falls are multi-factorial. These factors may be combined. The environment can play its role as well.

\section{The mechanism of falls: internal and external causes} Internal causes included loss of consciousness ( $1.8 \%$ of cases), insufficient balance or dizziness $(57.1 \%)$, seizure illnesses $(1.1 \%)$, dehydration $(0.7 \%)$, alcohol $(0.4 \%)$, vomiting in the last 24 hours $(0.4 \%)$ and other internal causes $(7.1 \%)$. No causes were found in $20.2 \%$ of cases and unknown causes were detected in $11.2 \%$ of cases.

External causes included stumbling/misstepping $(9.6 \%$ of cases), slipping (12.4\%), leaning on an unstable support (7.1\%), getting up from bed (26.6\%) and other external mechanisms (10.3\%). No causes were found in $17.0 \%$ of cases, and unknown causes were detected in $17.0 \%$ of cases.

$4.3 \%$ of falls were caused by slippery/wet floors, unsuitable footwear/socks. $11.3 \%$ of patients were barefoot. The environment of the facilities was not important in $67.2 \%$ of cases.

\section{Preventative interventions regarding falls}

Preventative interventions regarding falls (other than a bell) included a convertible bed in $78.4 \%$ of cases, brackets were used in $63.5 \%$ of patients, $18.8 \%$ were recommended to repose in bed and $2.1 \%$ needed an elevated toilet seat. 
It was statistically confirmed that brackets were used significantly more regarding confused patients $(p<0.001)$, restless patients $(p<0.05)$ and patients suffering from dementia $(p<0.01)$. We did not identify a statistically significant relationship between the use of brackets and the time of falls and the consequences of falls (Table 3 ).

Table 3. The relationship between the use of brackets and the mental condition before falls, consequences and the time of falls

\begin{tabular}{|c|c|c|c|c|c|}
\hline \multicolumn{6}{|c|}{ Value } \\
\hline & $N$ & $\chi^{2}$ & $\mathrm{df}$ & $p$ & $\begin{array}{c}\text { Statistically significant } \\
\text { difference }\end{array}$ \\
\hline confusion & 280 & 17.578 & 1 & $<0.001$ & $* * *$ \\
\hline restlessness & 280 & 5.989 & 1 & $<0.05$ & * \\
\hline dementia & 280 & 8.724 & 1 & $<0.01$ & $* *$ \\
\hline consequence of the fall & 280 & 0.524 & 2 & 0.763 & n. s. \\
\hline time of the fall & 280 & 3.423 & 3 & 0.331 & n. s. \\
\hline
\end{tabular}

$\chi^{2}=$ chi-square; $p=$ test of independence; $\mathrm{df}=$ degree of freedom; $\mathrm{n} . \mathrm{s} .=$ statistically insignificant difference.

* Statistically significant difference for the level of significance $(\alpha=0.05)$.

** Statistically significant difference for the level of significance $(\alpha=0.01)$.

$* * *$ Statistically significant difference for the level of significance $(\alpha=0.001)$.

\section{The consequences of falls, nursing care after falls, examinations and the influence on hospitalization}

$41.8 \%$ of falls were without injuries/consequences, $39.8 \%$ ended in light injuries which did not require medical treatment (superficial scratches, bruises) and $18.4 \%$ ended in mild injuries which required medical treatment (fractures, unconsciousness, concussions/CNS disruptions, CNS contusions). There were no severe injuries ending with the risk of permanent consequences, life-threatening injuries or death.

$93.3 \%$ of falls occurred in the absence of medical workers and only $6.4 \%$ occurred in their presence.

No treatment was necessary in $43.3 \%$ of cases, treatment by a nurse was required in $36.9 \%$ of cases, treatment by a doctor (stitches, fixation) was required in $22.7 \%$, surgery was required in $0.7 \%$, and other types of treatment were required in $1.8 \%$ of cases. The treatments could be combined. In our sample group, $29.8 \%$ of patients did not require any special examinations, consultation was carried out in $30.5 \%$ of cases, an $\mathrm{x}$-ray was carried out in $40.4 \%$, and computer tomography or magnetic resonance etc. were carried out in $14.9 \%$. The examinations could be combined.

$86.2 \%$ of patients' hospitalization was not prolonged. In $8.9 \%$ of cases, falls were the reason for prolonging the hospitalization and, in $3.2 \%$ falls were the reason for transfer to a different department. In $1.7 \%$ of cases, falls had a different influence on hospitalization, e.g. the change of the conditions of hospitalization.

\section{Discussion}

Most falls occurred at the departments of subsequent care (48.9\%). $44.3 \%$ occurred at internal departments. However, the lowest number of falls occurred at surgical departments (6.8\%). Most falls occurred in patients' rooms (78.0\%). The riskiest part of the day was between $22: 00$ and 5:59 (35.8\% of falls). $31.6 \%$ of patients fell from a bed. The risk of falls is higher with age. The average age of the patients who had experienced a fall was 76.9 years. $42.6 \%$ of falls occurred in the age group between 81 and 90 years, and $25.9 \%$ in the age group between 71 and 80 years. Gallardo et al. (2013) also confirm that the occurrence of falls rises with age. Healey and Darowski
(2012) claim that patients aged 85 years and older belong to the group with the highest risk of falls and injuries. Abreu et al. (2012) wanted to assess the prevalence of falls, understand their consequences, identify their causes and analyze intervention strategies for the decrease in their occurrence. It was a descriptive longitudinal study that was carried out between 2007 and 2009. Most falls occurred to partially dependent patients at the age between 64 and 74 years. Most falls occurred in patients' rooms and $36 \%$ of them had consequences. Our results correspond with the above-mentioned study of Abreu et al. (2012); we learned that most falls occurred in patients' rooms $(78.0 \%)$ and $93.3 \%$ of falls were in the absence of medical workers. Schwendimann et al. (2008) also focused on the monitoring of the occurrence of falls, their circumstances and consequences during hospitalization. The monitoring was carried out at clinical internal departments, the departments of geriatrics and surgery in Switzerland during a five-year period. Patients who had fallen were at an average age between 79.8 \pm 12.2 years. $57.2 \%$ were women. Older adults are at a higher risk of falls and are very vulnerable due to the increased morbidity and mortality (Clyburn and Heydemann, 2011; Oliver et al., 2010).

Our research identified a statistically significant relationship between gender and age. Our sample group of patients who had fallen included more women between 81 and 90 years. Men were at the age between 20 and 60 years. According to the Barthel test, which was completed during patient admission to the department where a fall occurred, $36.2 \%$ of the total 280 patients were highly dependent, and a medium stage of dependence was found in $25.5 \%$. According to the categories, $54.6 \%$ of patients were included in the 3rd category (patients who need greater supervision, or lucid patients incapable of moving out of bed even with assistance or by themselves on a wheelchair; patients who need almost full assistance or mentally altered patients who require personal supervision, restriction of movement or pharmacological sedation. Brackets were used for the prevention of falls of more than half of the patients who fell during hospitalization. They were used more when the patients were restless and suffered from dementia. It is clear that the use of brackets must be complemented with other interventions using modern technologies, such as monitoring techniques or sensory pads. 
A fall in a patient's medical history is one of the significant risk factors (Bóriková et al., 2018; Tinetti and Kumar, 2010). The medical history in the last 12 months of $39.8 \%$ of the patients in our sample group included a fall. The risk of a fall during admission was established in $77.7 \%$ of patients. We agree with the recommendation of Hitcho et al. (2004) to focus on preventative strategies specifically regarding this group of patients. Nurses must correctly identify the most vulnerable patients in the hospital and develop complex interventions to decrease the number of internal, external and environmental risk factors (Zhao and Kim, 2015).

Williams et al. (2014) carried out the analysis of 25000 reports on patient falls from 76 facilities which were uploaded to the UHC (University Health System ConSortium) system of incident reporting regarding patients with safety risks. Common factors of falls that resulted in severe injuries or death included patients older than 80 years, altered mental state, going to the toilet and pharmacotherapy with diuretics and anticoagulants. Tzeng (2010) confirms that patients suffering from a mental condition tend to have more severe injuries during falls than those who have no mental problems. Regarding geriatric patients, delirium, the history of falls and older age are the main risk factors in hospital preventative programmes regarding falls (Mazur et al., 2016). According to Härlein et al. (2011), elderly people with cognitive impairments are at three times higher risk of falls during hospitalization compared to those who have no cognitive impairments. Our results correspond with this conclusion; $34.4 \%$ of patients were confused and $20.0 \%$ suffered from dementia.

$46.5 \%$ of falls were related to patients who were hospitalized between 1 and 7 days. The hospital environment is one of the external risk factors, especially for elderly patients (Cumbler and Likosky, 2011). A positive finding is that, according to the doctors' and nurses' assessments at selected departments, the influence of the environment was not important in $67.2 \%$ of cases. The start of rehabilitation and using new compensation aids can be very risky (Cumminget al., 2008). 25.9\% of patients at the selected departments started rehabilitation and $12.8 \%$ began using new compensation aids.

Problems with evacuation or incontinence are also risk factors (Hitcho et al., 2004). 28.7\% of the patients in our sample group were incontinent. Another risk factor is problems with food or liquid intake (Vivanti et al., 2011). 12.1\% of patients in our sample group had these problems.

$41.8 \%$ of cases in our sample group were without injuries or other consequences, $39.8 \%$ caused light injuries, $18.4 \%$ caused mild injuries where a doctor's treatment was necessary (fractures, unconsciousness, CNS disruptions or CNS contusions). There were no severe injuries ending with the risk of permanent consequences, life-threatening injuries or death. Almost half of the patients underwent an x-ray examination.
In $8.9 \%$ of the cases, a fall was the reason for prolonging the patient's hospitalization and, in 3.2\%, a fall was the reason for transfer to another department. Jorgensen et al. (2015) carried out a study in Danish hospitals between 2000 and 2012. They focused on severe injuries in patients over 65 years during hospitalization. They learned that patients who suffered from dementia, osteoporosis, a stroke, depression, Parkinson's disease and chronic obstructive lung disease were at a higher risk of severe injuries during a fall and recommended a greater attention of medical workers for the decrease of their incidence. The articles by the team members of our project will deal with the relationships between the personal anamneses of patients who have experienced a fall and also a potential influence of pharmacotherapy.

\section{Conclusions}

Regarding the prevention of falls, a multilateral approach and the active involvement of experts from various disciplines appear to be effective. A quality organizational culture and teamwork and communication are necessary to achieve such prevention co-ordination. Considering the fact that most falls occurred at night in the absence of medical workers, we recommend changes in the control system and interventions using modern technologies and systems, such as monitoring techniques or sensory pads. It is important to consider individual risk factors of hospitalized patients when applying preventative measures. The knowledge and the experience of nursing personnel are crucial for their establishment. In January 2018, the monitored departments began an intervention programme whose goal was to decrease the occurrence of falls. The departments also bought modern compensation aids used for the prevention of falls. In the future, we intend to focus on the comparison of patients who have not experienced a fall, and to determine specific independent risk factors regarding patients hospitalized at selected departments in the selected hospitals in South Bohemia involved in this project.

\section{Research limitations}

We analyzed falls in 4 hospitals in South Bohemia at 16 selected departments with the highest occurrence of falls in the previous years.

\section{Conflict of interests}

The authors have no conflict of interests to disclose.

\section{Acknowledgements}

Supported by the programming project of the Ministry of Health of the Czech Republic, reg. no. 16-33463A. 


\section{Faktory spojené s pády v nemocničním prostředí: důsledky pro ošetřovatelskou péči}

\section{Souhrn}

Cíl: Cílem výzkumu bylo provést analýzu pádů hospitalizovaných pacientů za rok 2017, ke kterým došlo na 16 vybraných odděleních ve 4 nemocnicích Jihočeského kraje. Pády hospitalizovaných pacientů patří k nejčastějším nežádoucím událostem, ke kterým dochází v nemocničním prostředí.

Metodika: Data o pádech z jednotlivých nemocnic byla pověřenými pracovníky kódována a vkládána do databáze „Monitoring rizikových faktorů pádů a jejich analýza“, následně byla provedena jejich statistická analýza za pomoci statistického programu SASD. Bylo analyzováno celkem 280 pádů hospitalizovaných pacientů.

Výsledky: Nejvíce pádů se odehrálo na odděleních skupiny následné péče - 48.9 \% pádů, na interních odděleních se odehrálo $44.3 \%$ pádů, nejméně pak na chirurgických odděleních - $6.8 \%$ pádů. Téměř polovina (46.5 \%) pádů se týkala pacientů s délkou hospitalizace 1-7 dní. Průměrný věk pacientů, u kterých došlo k pádu, byl 76.9 let. Nejvíce pádů se odehrálo na pokojích pacientů $-78.0 \%$, v $93.3 \%$ se jednalo o pády pacientů bez přítomnosti zdravotníků. Pád v anamnéze v posledních 12 měsících měla více než třetina (39.8 \%) pacientů. Nejrizikovější bylo časové období mezi 22:00 až 5:59 hodinou (35.8 \% pádů). Nejčastěji se jednalo o pád pacienta z lůžka - 31.6 \%. Bez poranění/následků se obešla téměř polovina pádů - $41.8 \%$. Jako nejčastější vnitřní př́ičina, která přispěla k pádu pacienta, byla určena porucha rovnováhy nebo závrat' (57.1 \% př́ípadů), třetina pacientů (34.4 \%), u nichž došlo během hospitalizace k pádu, byla zmatená.

Závěr: Vzhledem k výše zmíněným výsledkům doporučujeme změnu v systému kontrol ošetřujícím personálem a intervence s využitím moderních informačních technologií a systémů.

Klíčová slova: Analýza pádů; Česká republika; Hospitalizovaní pacienti; Ošetřovatelská péče; Rizikové faktory

\section{References}

1. Abreu C, Mendes A, Monteiro J, Santos FR (2012). Falls in hospital settings: a longitudinal study. Rev Lat Am Enfermagem 20(3): 597-603. DOI: 10.1590/S0104-11692012000300023.

2. Ang E, Mordiffi SZ, Wong HB (2011). Evaluating the use of a targeted multiple intervention strategy in reducing patient falls in an acute care hospital: a randomized controlled trial. J Adv Nurs 67(9): 1984-1992. DOI: 10.1111/j.13652648.2011.05646.x.

3. Barker AL, Morello RT, Wolfe R, Brand CA, Haines TP, Hill KD, et al. (2016). 6-PACK programme to decrease fall injuries in acute hospitals: cluster randomised controlled trial. BMJ 352: h6781. DOI: 10.1136/bmj.h6781.

4. Barrett MB, Vizgirda VD, ZhouY (2017). Registered nurse and patient care technician perceptions of toileting patients at high fall risk. Medsurg Nursing 26(5): 317-323.

5. Bayen E, Jacquemot J, Netscher G, Agrawal P, Tabb Noyce L, Bayen A (2017). Reduction in fall rate in dementia managed care through video incident review: Pilot Study. J Med Internet Res 19(10): e339. DOI: 10.2196/jmir.8095.

6. Bittencourt VLL, Graube SL, Stumm EMF, Battisti IDE, Loro MM, Winkelmann ER (2017). Factors associated with the risk of falls in hospitalized adult patients. Rev Esc Enferm USP 51:e03237. DOI: 10.1590/S1980-220X2016037403237.

7. Bóriková I, Žiaková K, Tomagová M, Záhumenská J (2018). The risk of falling among older adults in long-term care: screening by the Morse Fall Scale. Kontakt 20(2): e111-e119. DOI: 10.1016/j.kontakt.2017.11.006.

8. Bradley SM, Karani R, McGinn T, Wisnivesky J (2010). Predictors of serious injury among hospitalized patients evaluated for falls. J Hosp Med 5(2): 63-68. DOI: 10.1002/ jhm.555.

9. Cameron ID, Murray GR, Gillespie LD, Robertson MC, Hill KD, Cumming RG, Kerse N (2010). Interventions for preventing falls in olderpeople in nursing care facilities and hospitals. Cochrane Database SystRev 20(1): CD005465. DOI: 10.1002/14651858. CD005465.pub2.

10. Chang CM, Chen MJ, Tsai CY, Ho LH, Hsieh HL, Chau YL, Liu CY (2011). Medical conditions and medications as risk factors of falls in the inpatient older people: a case-control study. Int J Geriatr Psychiatry 26(6): 602-607. DOI: 10.1002/ gps.2569.
11. Clyburn TA, Heydemann JA (2011). Fall prevention in theelderly: Analysis and Comprehensive Review of Methods Used in the Hospital and in the Home. J Am Acad Orthop Surg 19(7): 402-409. DOI: 10.5435/00124635-201107000-00003.

12. Cox J, Thomas-Hawkins C, Pajarillo E, De Gennaro S, Cadmus E, Martinez M (2015).Factors associated with falls in hospitalized adult patients. Appl Nurs Res 28(2): 78-82. DOI: 10.1016/j. apnr.2014.12.003.

13. Cumbler E, Likosky D (2011). In-hospital falls: Evaluation and response. Continuum (Minneap Minn) 17(5): 1063-1076. DOI: 10.1212/01.con.0000407060.48155.05.

14. Cumming RG, Sherrington C, Lord SR, Simpson JM, Vogler C, Cameron ID, Naganathan V (2008). Cluster randomised trial of a targeted multifactorial intervention to prevent falls among older people in hospital. BMJ 336(7647): 758-760. DOI: 10.1136/bmj.39499.546030.BE.

15. Cuttler SJ, Barr-Walker J, Cuttler L (2017). Reducing medicalsurgical inpatient falls and injuries with videos, icons and alarms. BMJ Open Qual 6(2): e000119. DOI: 10.1136/ bmjoq-2017-000119.

16. Dunne TJ, Gaboury I, Ashe MC (2014). Falls in hospital increase length of stay regardless of degree of harm. J Eval Clin Pract 20(4): 396-400. DOI:10.1111/jep.12144.

17. Dykes PC, Carroll DL, Hurley A, Lipsitz S, Benoit A, Chang F, Middleton B (2010). Fall prevention in acute care hospitals: a randomized trial. JAMA 304(17): 1912-1918. DOI: 10.1001/ jama.2010.1567.

18. Gallardo AM, Morales-Asencio Asencio JM, Canca-Sanchez JC, Barrero-Sojo S, Perez-Jimenez C, Morales-Fernandez, et al. (2013). Instruments for assessing the risk of falls in acute hospitalized patients: A systematic review protocol. J Adv Nurs 69(1): 185-193. DOI: 10.1111/j.1365-2648.2012.06104.x.

19. Ganz DA, Huang C, Saliba D, Shier V (2013). Preventing falls in hospitals: A toolkit for improving quality of care. RAND Corporation, Boston University School of Public Health and ECRI. Rockville, MD: Agency for Healthcare Research and Quality. AHRQ Publication no. 13-0015-EF.

20. Godlock G, Christiansen M, Feider L (2006). Implementation of an evidence-based patient safety team to prevent falls in inpatient medical units. Medsurg Nurs 25(1): 17-23.

21. Härlein J, Halfens RJ, Dassen T, Lahmann NA (2011). Falls in older hospital inpatients and the effect of cognitive impairment: a secondary analysis of prevalence studies. J Clinical Nurs 20: 175-183. DOI: 10.1111/j.1365-2702.2010.03460.x. 
22. Healey F (2016). Preventing falls in hospitals: Tackling risk factors should be a clinical priority. BMJ: 352. DOI: 10.1136/ bmj.i251.

23. Healey F, Darowski A (2012). Older patients and falls in hospital. Clinical Risk 18(5): 170-176. DOI: 10.1258/ cr.2012.012020.

24. Healey F, Scobie S (2007). Slips, trips and falls in hospital. Patient Safety Observatory, 3rd report. London: National Patient Safety Agency.

25. Hefner JL, McAlearney AS, Mansfield J, Knupp AM, Moffatt-Bruce SDA (2015). Falls wheel in a large academic medical center: An intervention to reduce patient falls with harm. J Healthc Qual 37(6): 374-380. DOI: 10.1097/ JHQ.0000000000000011.

26. Hitcho EB, Krauss MJ, Birge S, Dunagan WD, Fischer I, Johnson S, et al. (2004). Characteristics and circumstances of falls in a hospital setting: A prospective analysis. J Gen Inter Med 19(7): 732-739. DOI: 10.1111/j.1525-1497.2004.30387.x.

27. Horová J, Brabcová I, Krocová J (2017). The effectiveness of intervention programs for preventing patients from falls. Kontakt 19(2): 105-115. DOI: 10.1016/j.kontakt.2017.04.003.

28. Jørgensen TSH, Hansen AH, Sahlberg MIE, Gislason GH, Torp-Pedersen C, Andersson C, Holm E (2015). Nationwide time trends and risk factors for in-hospital falls-related major injuries. Int J Clin Pract 69(6): 703-709. DOI: 10.1111/ ijcp.12624.

29. Kang YO, Song R (2015). Identifying characteristics of fall episodes and fall-related risks of hospitalized patients. Journal of Muscle and Joint Health 22(3): 149. DOI: 10.5953/ JMJH.2015.22.3.149.

30. Katsulis Z, Ergai A, Leung WY, Schenkel L, Rai A, Adelman J (2010). Iterative user centered design for development of a patient-centered fall prevention toolkit. Applied Ergonomics 56: 117-126. DOI: 10.1016/j.apergo.2016.03.011.

31. King B, Pecanac K, Krupp A, Daniel Liebzeit D, Mahoney J (2018). Impact of fall prevention on nurses and care of fall risk patients. Gerontologist 58(2): 331-340. DOI: 10.1093/geront/ gnw156.

32. Lamis RL, Kramer JS, Hale LS, Zackula RE, Berg GM (2012). Fall risk associated with inpatient medications. Am J Health Syst Pharm 69: 1888-1894. DOI: 10.2146/ajhp110723.

33. Lang AR, Kwok TC, Fioratou E, LeJeune I, Sharples S (2014). User-centred design of patient information for hospital admissions and patient experience. In: Sharples S, Shorrock S (Eds). Contemporary Ergonomics and Human Factors. CRC Press, pp. 203-210.

34. Lee DCA, Pritchard E, McDermott F, Haines TP (2014). Falls prevention education for older adults during and after hospitalization: a systematic review and meta-analysis. Health Educ J 73: 530-544. DOI: 10.1177/0017896913499266.

35. Luzia MF, Argenta C, Almeida MA, Lucena AF (2018). Conceptual definitions of indicators for the nursing outcome "Knowledge: Fall Prevention". Rev Bras Enferm 71(2): 431-439. DOI: 10.1590/0034-7167-2016-0686.

36. Mazur K, Wilczyński K, Szewieczek J (2016).Geriatric falls in the context of a hospital fall prevention program: delirium, low body mass index, and other risk factors. Clin Interv Aging 11: 1253-1261. DOI: 10.2147/CIA.S115755.

37. McKechnie D, Pryor J, Fisher MJ (2017). Predicting falls in the inpatient setting. JARNA 20(3): 14-19.
38. Oliver D, Healey F, Haines T (2010). Preventing falls and fallrelated injuries in hospitals. Clin Geriatr Med 26(4): 645-692. DOI: 10.1016/j.cger.2010.06.005.

39. Oliver D, Hopper A, Seed P (2000). Do hospital fall prevention programs work? A systematic review. J Am Geriatr Soc 48: 1679-1689. DOI:10.1111/j.1532-5415.2000.tb03883.x.

40. Pokojová R, Bártlová S (2018). Ensuring a sufficient number of personnel as part of the safety culture in medical facilities. Kontakt 20(1): e11-e16. DOI: 10.1016/j.kontakt.2017.10.002.

41. Pokorná A, Búřilová P, Štrombachová V, Dolanová D (2017). Centrální systémové hlášení nežádoucích událostí - Metodika Nežádoucí událost, PÁD. Ústav zdravotnických informací a statistiky ČR. [online] [cit. 2018-07-15]. Available from: http:// shnu.uzis.cz/res/file/metodicke_dokumenty/pad_metodika_ plna_verze_metodiky(1).pdf

42. Rheaume J, Fruh S (2015). Retrospective cases reviews of adult inpatient falls in the acute care setting. Medsurg Nurs 24(5): 318-324.

43. Shumba C, Abraham S (2017). Patient falls in the acute care hospital setting as perceived by the frontline staff. Prensa Med Argent 103(3). DOI: 10.4172/lpma.1000251.

44. Schwendimann R, Bühler H, Geest S, Milisen K (2008). Characteristics of hospital inpatient falls across clinical departments. Gerontology 54(6): 342-348. DOI: 10.1159/000129954.

45. Tinetti ME, Kumar C (2010). The patient who falls: "It's always a trade-off" JAMA 303(3): 258-266. DOI: 10.1001/ jama.2009.2024.

46. Topinková E (2005). Geriatrie pro praxi. Praha: Galén.

47. Twibell RS, Siela D, Sproat T, Coers G (2015). Perceptions related to falls and fall prevention among hospitalized adults. Am J Crit Care 24(5): e78-85. DOI: 10.4037/ajcc2015375.

48. Tzeng HM (2010). Inpatient falls in adult acute care settings: influence of patients' mental status. J Adv Nurs 66(8): 17411746. DOI: 10.1111/j.1365-2648.2010.05343.x.

49. Tzeng HM, Yin CY (2014). Engaging as an innovative approach to engage patients in their own fall prevention care. Patient Prefer Adherence 8: 693-700. DOI: 10.2147/PPA.S62746.

50. Vivanti A, Ward N, Haines T (2011). Nutritional status and associations with falls, balance, mobility and functionality during hospital admission. J Nutr Health 15(5): 388-391. DOI: 10.1007/s12603-010-0302-8.

51. Votruba L, Graham B, Wisinski J, Syed A (2016). Video monitoring to reduce falls and patient companion costs for adult inpatients. Nurs Econ 34(4): 185-189.

52. Williams T, Szekendi M, Thomas S (2014). Ananalysis of patient falls and fall prevention programs across academic medical centers. J Nurs Care Qual 29(1): 19-29. DOI: 10.1097/ NCQ.0b013e3182a0cd19.

53. Wong CA, Recktenwald AJ, Jones ML,Waterman BM, Bollini ML, Dunagan WC (2011). The cost of serious fall-related injuries at three Midwestern hospitals. Jt Comm J Qual Patient Saf 37(2): 81-87. DOI: 10.1016/S1553-7250(11)37010-9.

54. Zhao YL, Kim H (2015). Older adult inpatient falls in acute care hospitals: intrinsic, extrinsic, and environmental factors. J Gerontol Nurs 41(7): 29-43. DOI: 10.3928/0098913420150616-05. 